\title{
Human Rights Laws and Authorship Norms
}

Roberta Rosenthal Kwall

Follow this and additional works at: https://open.mitchellhamline.edu/mhlr

Part of the Human Rights Law Commons, and the Intellectual Property Law Commons

\section{Recommended Citation}

Kwall, Roberta Rosenthal (2020) "Human Rights Laws and Authorship Norms," Mitchell Hamline Law Review. Vol. 46 : Iss. 3 , Article 1.

Available at: https://open.mitchellhamline.edu/mhlr/vol46/iss3/1

This Article is brought to you for free and open access by the Law Reviews and Journals at Mitchell Hamline Open Access. It has been accepted for inclusion in Mitchell Hamline Law Review by an authorized administrator of Mitchell Hamline Open Access. For more information, please contact sean.felhofer@mitchellhamline.edu. (c) Mitchell Hamline School of Law

\section{$\mathrm{MH}$} MITCHELL | HAMLINE OPEN ACCESS Setod fin mitchellhamline.edu 


\title{
HUMAN RIGHTS LAWS AND AUTHORSHIP NORMS ${ }^{1}$
}

\author{
Roberta Rosenthal Kwall *
}

\section{INTRODUCTION}

When The Soul of Creativity was published nearly ten years ago, the role of human rights in Intellectual Property law was a relatively uncharted territory, and this is still essentially the case. It is also still the case that moral rights laws in the United States are relatively weak compared to the vast majority of other nations, and the 2019 Report of the Register of Copyrights does little to change our current reality. ${ }^{3}$ Although the Report contained some useful recommendations, it did not recommend broadening the scope of moral rights to include a wider variety of subject matter and also declined to revisit the exclusion of the work for hire doctrine to the current application of the Visual Artists Rights Act.

The history of the International Bill of Human Rights demonstrates that, although there may not have been a universal consensus as to whether moral rights are human rights, there was a significant recognition that these interests are deemed worthy of protection in a human rights framework. ${ }^{4}$ Therefore, rather than focusing on whether moral rights are within the scope of human rights, the better question is whether the widespread recognition of moral rights means they should be considered as "authorship norms.” I argue that we must develop a broader spectrum of theoretical justifications for copyright law than the existing conventional framework that is currently invoked to justify copyright protection in the United States. In

\footnotetext{
* Roberta Rosenthal Kwall is the Raymond P. Niro Professor at DePaul University College of Law. She has written extensively on author's rights, copyright law, creativity theory, Jewish law and culture, and lectures extensively on these topics internationally. Professor Kwall is the author of over thirty-five academic articles and book chapters on these topics, as well as three monographs published by Stanford UP, Oxford UP, and Rowman \& Littlefield. She is also a frequent author of Opeds and articles in the popular media.

"The original version of this article, without the "Introduction" section, was published in: Roberta R. KWall, The Soul of Creativity: Forging a Moral Rights LaW For the UnITED STATES ch. 9 (2009). Copyright (C) 2009 by the Board of Trustees of the Leland Stanford Jr. University.

${ }^{2}$ Roberta R. Kwall, The Soul of Creativity: Forging a Moral Rights Law for THE United STATES (Stanford University Press, 2009).

${ }^{3}$ U.S. COPYright OfFice, AUthors, ATtribution, AND INTEgrity: EXAMining MORAL RightS IN THE UNITED STATES (2019), https:/www.copyright.gov/policy/moralrights/fullreport.pdf.

' See G.A. Res. 217 (III) A, Universal Declaration of Human Rights art. 27(2) (Dec. 10, 1948) [hereinafter UDHR].
} 
other words, it is critical to create a normative culture that recognizes a more fluid view of copyright, allowing for the incorporation of enhanced moral rights in our legal system.

As Laurence Helfer notes, "Human rights and intellectual property, two bodies of law that were once strangers, are now becoming increasingly intimate bedfellows." "Given this intimacy, can we justify enhanced protection for moral rights on the ground that they are human rights? The basis for situating moral rights within a human rights discourse lies in the dignity interest with which both areas are concerned.

Three documents compose the core legal framework for the "International Bill of Human Rights." The first of these key instruments, the Universal Declaration of Human Rights (UDHR), was adopted in $1948 .{ }^{6}$ As a declaration rather than a covenant, the UDHR does not represent binding international law. However, according to many authorities, the UDHR has the force of "customary" international law and is considered an authentic interpretation of the United Nations Charter. 'The other two instruments composing the International Bill of Human Rights are covenants and were passed decades later. ${ }^{8}$

Mary Ann Glendon skillfully documents the story of how the UDHR came about in $A$ World Made New. Although she does not specifically address moral rights in her book, her treatment underscores that World War II and the Holocaust were the events motivating the framers of the UDHR. ${ }^{9}$ During the drafting process, the UDHR delegates repeatedly

\footnotetext{
${ }^{5}$ Laurence R. Helfer, Human Rights and Intellectual Property: Conflict or Coexistence?, 5 Minn. Intell. Prop. Rev. 47 (2003).

${ }^{6}$ UDHR, supra note 4.

7 David Shiman, Economic and Social Justice: A Human Rights Perspective 7-8 (1999), http://hrlibrary.umn.edu/edumat/pdf/TB1.pdf.

${ }^{8}$ See infra notes 17-23 and accompanying text.

9 Mary Ann Glendon, A World Made New: Eleanor Roosevelt and the Universal Declaration of Human Rights (2001); see also James W. Nickel, Making Sense of Human Rights: Philosophical Reflection on the Universal Declaration OF Human Rights 1 (1987) ("Today's idea of human rights is a compound that was brewed in the cauldron of World War II."). Professor Paul Torremans has stated that the UDHR came about based on a recognition that during the war, "science and technology as well as copyright based propaganda had been abused for atrocious purposes by those who lost the war" and that such abuses "had to be prevented for the future." Paul Torremans, Copyright as Human Right, in Copyright And Human Rights: FreEdom of Expression-Intellectual Property-Privacy 5 (Paul L.C. Torremans ed., 2004).
} 
condemned the numerous atrocities committed by the Nazis during the war, including forced intellectual labor, such as that suffered by Dina Babbitt. ${ }^{10}$

The key UDHR provision dealing with human rights in relation to moral rights is Article 27, Paragraph 2, which provides that "[e]veryone has the right to the protection of the moral and material interests resulting from any scientific, literary or artistic production of which he is the author." Interestingly, the UDHR language does not require an author to create a copyrightable work to secure protection. This provision was extremely controversial because there was no international consensus on how interests in intellectual creations should be protected. The protection of authors' moral interests was added by the French delegate who was prompted by the lack of protection for this interest in the Anglo-American copyright regimes. ${ }^{12}$ Despite the objection by American and British delegates to the "moral and material interests" inclusion on the ground that this type of right should more properly be considered within the domain of copyrights, the provision ultimately was included after considerable discussion. ${ }^{13}$ Still, there was disagreement with respect to whether the protection of interests in intellectual property should be seen as a basic human right. ${ }^{14}$ Even with respect to those who voted favorably for the provision, there were mixed and varied motives. Specifically, not all of the delegates who cast a favorable vote necessarily agreed with the French delegate's concern for moral rights. ${ }^{15}$ Nonetheless, according to Paul Torremans, the UDHR embodies "the

${ }^{10}$ See Kwall, supra note 2, at 100 n.81-82 and accompanying text (discussing artist Dina Gottliebova Babbitt's experience of forced painting in Auschwitz during World War II and the appropriation of her portraits by Dr. Josef Mengele, the infamous Nazi "Angel of Death").

"The balancing provision, Article 27, Paragraph 1, provides that "[e]veryone has the right to freely participate in the cultural life of the community, to enjoy the arts and to share in scientific advancement and its benefits." See infra notes 27, 106, 107, and accompanying text. Additionally, Article 19 of the UDHR protects the right to freedom of opinion and expression. The right to the protection of interests in intellectual creations was discussed in four of the seven formal sessions in which the UDHR was drafted. Peter K. Yu, Reconceptualizing Intellectual Property Interests in a Human Rights Framework, 40 U.C. Davis L. Rev. 1039, 1051 (2007).

${ }^{12} \mathrm{Yu}$, supra note 11, at 1052-54.

${ }^{13}$ Id. at $1056-58$.

${ }^{1 "} I d$. at 1070 .

${ }^{15}$ In addition to concern for authors' rights, Yu notes the following distinct rationales at play during the voting process: a populist view that $27(2)$ also safeguards the interests of everyone; the idea that these rights were already included in the American Declaration on the Rights and Duties of Man that was adopted by more than twenty-one Latin American countries and the United States; a concern for the internationalization of copyright law; and an instrumentalist view that recognition of this right ultimately would support other important goals such as intellectual freedom. Id. at 1056-58. 
single most authoritative source of human rights norms" and has served as a basis for validating authors' moral rights in several cases. ${ }^{16}$

The second instrument providing additional authoritative support for a human rights framework in intellectual property is the International Covenant on Economic, Social and Cultural Rights of 1966 (ICESCR). ${ }^{17}$ As a covenant, the ICESCR represents binding international law for over 170 member nations. ${ }^{18}$ Although the United States signed the covenant in 1979, to date, it has not been ratified in this country. ${ }^{19}$ Therefore, the ICESCR is not binding here, unlike the Berne Convention or the Agreement on TradeRelated Aspects of Intellectual Property Rights (TRIPS). Article 15(1)(c) of the ICESCR essentially borrowed language from Article 27 of the UDHR by recognizing the right of everyone " $[\mathrm{t}$ ] benefit from the protection of the moral and material interests resulting from any scientific, literary or artistic production of which he is the author." ${ }^{20}$ This language also is similar to that of Article 27(2) of the UDHR in that authors of works that are not copyrightable can be protected. The material interests referred to in the ICESCR were based on the right to just remuneration for intellectual labor, while the moral interests were based on the French droit moral. Significantly, the legislative history of the ICESCR also illustrates an ongoing debate over intellectual property's worthiness as a human right. ${ }^{21}$

\footnotetext{
${ }^{16}$ Torremans, supra note 9, at 7 (discussing French cases involving Charlie Chaplin and John Huston).

${ }^{17}$ G.A. Res. 2200A (XXI), International Covenant on Economic, Social and Cultural Rights, (Dec. 16, 1966), https://www.ohchr.org/en/professionalinterest/pages/cescr.aspx [hereinafter ICESCR] [https://perma.cc/PLK5-S46Z]. The ICESCR entered into force on January 3, 1976 .

${ }_{18}$ Status of Treaties: International Covenant on Economic, Social and Cultural Rights, United Nations Treaty Collection, https://treaties.un.org/Pages/ViewDetails.aspx? ${ }^{\text {src }}=$ TREATY\&mtdsg_no $=$ IV-

$3 \&$ chapter=4\&clang=_en [https://perma.cc/T6CV-WMHC] (last visited Jan. 16, 2020).

${ }^{19}$ Shiman, supra note 7 , at 9 :

According to the law of treaties, a government that has signed but not ratified a treaty (like the Covenant) must "refrain from acts which would defeat the object and purpose of [the] treaty ... . until it shall have made its intention clear not [to] become a party. ..." Unfortunately, courts in the USA are not likely to attach much importance to this rule if an action were brought before that claims the USA is defeating the object and purpose of the Covenant.

${ }^{20}$ ICESCR, supra note 17, art. 15(1)(c).

${ }^{21}$ At the time, few observers considered the rights of authors and inventors to be human rights, yet "these rights were recognized at the birth of the international human rights movement.” See Laurence R. Helfer, Collective Management of Copyright and Human Rights: An Uneasy Alliance, in Collective Management of Copyright and Related RigHTs 85 (Daniel J. Gervais ed., 2006) [hereinafter Helfer, An Uneasy Alliance].
} 
Finally, the third instrument, the International Covenant on Civil and Political Rights (ICCPR) was passed in 1966 and became effective on March 23, $1976 .{ }^{22}$ The United States fully ratified the ICCPR in 1992. Although the ICCPR does not specifically address intellectual property rights, it does provide protection for the freedom of expression. ${ }^{23}$

Since the beginning of the twenty-first century, the United Nation's Committee on Economic, Social and Cultural Rights (CESCR) has increased its support for a human rights framework for intellectual property rights by focusing on the connection between the protection for intellectual creations and human dignity. ${ }^{24}$ The CESCR published a 2001 Statement on

${ }^{22}$ G.A. Res. 2200A (XXI), International Covenant on Civil and Political Rights (Dec. 16, 1966), https://www.ohchr.org/en/professionalinterest/pages/ccpr.aspx [hereinafter ICCPR] [https://perma.cc/2PFW-9EAG]. This covenant addresses freedom of expression and the right to "receive and impart information and ideas of all kinds ... either orally, in writing, or in print, in the form of art, or through any other media.” Id. art. 19, para. 2. The International Bill of Human Rights also includes two Optional Protocols, neither of which was signed by the United States.

${ }^{23}$ Article 19, Paragraph 3, of the ICCPR is the balancing provision, stating that the exercise of rights in Paragraph 2 may be subject to restrictions to respect the right or reputations of others.

Some scholars see freedom of expression as the key to understanding moral rights protection. See Leslie Kim Treiger-Bar-Am, The Moral Right of Integrity: A Freedom of Expression, in 2 New Directions in Copyright Law 128 (Fiona Macmillan \& Kathy Bowrey eds., 2006). In addition, in the Hugo case, the court relied on Article 10 of the European Convention of Human Rights, which is an effort by the Council of Europe to strengthen human rights commitments. See KwALL, supra note 2, at 43-44 n.64 (discussing Pierro Hugo v. Societe Plon, S.S. Cass. Cour d'appel [CA] [regional court of appeal] Paris, 4e ch., sect. B, Dec. 19, 2008, JCP 2009, II, 10038, note Christophe Caron (Fr.)). Substantively, the European Convention is comparable to the ICCPR, and it includes protection for freedom of expression. Compliance with the European Convention is achieved through the Court of Human Rights. See Louis Henkin etal., Human Rights 339,552 (1999). Of course, freedom of expression can be used not only as a justification for moral rights, but also as a defense by those who seek to violate the moral rights of others. See Treiger-Bar-Am, supra, at 158 (noting that "while understanding section 80 [the codified right of integrity in the UK Copyright, Designs and Patents Act of 1988] as a freedom of expression would entail a liberal reading of claims, it would entail a liberal reading of defences as well”).

${ }^{24}$ The Committee "is a supervisory body of eighteen human rights experts who monitor the implications of the Covenant.” Helfer, An Uneasy Alliance, supra note 21, at 87. 
Article 15(1)(c) ${ }^{25}$ and a 2005 General Comment interpreting this provision. ${ }^{26}$ In its 2001 Statement, the CESCR recommended that states take a balancing approach between protecting the intellectual property rights contained in Article 15(1)(c) and "the right to take part in cultural life and to enjoy the benefits of scientific progress" as specified in the balancing provisions of the ICESCR Articles 15(1)(a) and (b). ${ }^{27}$ This Statement underscores that the key tension in a human rights framework is the protection of an author's moral and material interests versus the right of the public to enjoy and share in the benefits of works. The Statement provides that "[t]he end which intellectual property protection should serve is the objective of human well-being, to which international human rights instruments give legal expression., ${ }^{28}$ Thus, it "encourages the development of intellectual property systems and the use of intellectual property rights in a balanced manner that meets the objective of providing protection for the moral and material interests of authors," while simultaneously promoting "the enjoyment of these and other human rights." ${ }^{29}$

The 2005 General Comment picks up where the CESCR 2001 Statement leaves off, lending additional support for a human rights framework for moral interests. ${ }^{30}$ It begins by stating that the right to the protection of interests in intellectual creations "derives from the inherent dignity and worth of all persons" and that these rights should be contrasted with "most legal entitlements recognized in intellectual property systems." ${ }^{31}$ The Committee considered moral and material interests to be of primary

${ }^{25}$ U.N. Comm. on Econ., Soc., \& Cultural Rights [CESCR], Substantive Issues Arising in the Implementation of the International Covenant on Economic, Social and Cultural Rights [ICESCR], U.N. Doc. E/C.12/2001/15 (Dec. 14, 2001), https:/www2.ohchr.org/english/bodies/cescr/docs/statements/E.C.12.2001.15HRIntelproperty.pdf [hereinafter CESCR 2001 Statement] [https://perma.cc/A6CD-6QLT].

${ }^{26}$ CESCR, General Comment No. 17: The Right of Everyone to Benefit from the Protection of the Moral and Material Interests Resulting from any Scientific, Literary or Artistic Production of Which He Is the Author, U.N. Doc. E/C.12/GC/17 (Jan. 12., 2006), https://undocs.org/en/E/C.12/GC/17 [hereinafter General Comment No. 17 [https://perma.cc/2M94-KRJ3].

${ }^{27}$ CESCR 2001 Statement, supra note 25, II 4; see also infra note 107 and accompanying text.

${ }^{28}$ CESCR 2001 Statement, supra note 25, 14.

${ }^{29}$ Id. CESCR also contrasted intellectual property rights that "may be allocated, limited in time and scope, traded, amended and even forfeited," with human rights that "are fundamental, inalienable and universal entitlements belonging to individuals, and in some situations groups of individuals and communities." Id. $\mathbb{1} 6$.

${ }^{30}$ Laurence Helfer notes that such comments by the CESCR are interpretations rather than binding law and thus can be viewed by governments as "aspirational." Laurence R. Helfer, International Rights Approaches to Intellectual Property: Toward a Human Rights Framework for Intellectual Property, 40 U.C. DAvis L. REv. 971, 999 (2007).

${ }^{31}$ General Comment No. 17, supra note 26, II 1. 
importance to the dignity of the author because they safeguard "the personal link between authors and their creations." ${ }^{32}$ In speaking of "moral interests," the General Comment referred to the intention of article 27(2) of the UDHR as recognizing the "intrinsically personal character of every creation of the human mind and the ensuing durable link between creators and their creations." ${ }^{33}$ According to the General Comment, the moral rights within the scope of the ICESCR include the rights of attribution and integrity. ${ }^{34}$ Thus, individual authors' moral interests are indeed conceived of as human rights. $^{3.5}$

${ }^{32}$ Id. $\llbracket 2$.

${ }^{33}$ Id. $\llbracket 12$.

"s "[T]he Committee considers that 'moral interests' in article 15, paragraph 1(c) include the right of authors to be recognized as the creators of their scientific, literary and artistic productions and to object to any distortion, mutilation or other modification of, or other derogatory action in relation to, such productions, which would be prejudicial to their honour or reputation," Id. II 13 (citing Berne Convention for the Protection of Literary and Artistic Works art. 6bis, Sept. 9, 1886, as revised at Paris on July 24, 1971 and amended in 1979, S. Treaty Doc. No. 99-27 (1986)).

${ }^{35}$ Id. II 7. Here, CESCR reiterates that its definition of "authors" was limited in scope to natural persons or groups of individuals and thus precludes human rights recognition of corporate authorship such as works made for hire. It does, however, acknowledge that communities might be authors in some situations. Id. I 8 . Moreover, according to the Comment, ICESCR provides a floor for human rights protection, which makes up the "core obligations" of the Covenant. The list of core obligations under General Comment No. 17, supra note 26 , 1939 includes:

(a) To take legislative and other necessary steps to ensure the effective protection of the moral and material interests of authors;

(b) To protect the rights of authors to be recognized as the creators of their scientific, literary and artistic productions and to object to any distortion, mutilation or other modification of, or other derogatory action in relation to, their productions that would be prejudicial to their honour or reputation;

(c) To respect and protect the basic material interests of authors resulting from their scientific, literary or artistic productions, which are necessary to enable those authors to enjoy an adequate standard of living;

(d) To ensure equal access, particularly for authors belonging to disadvantaged and marginalized groups, to administrative, judicial or other appropriate remedies enabling authors to seek and obtain redress in case their moral and material interests have been infringed;

(e) To strike an adequate balance between the effective protection of the moral and material interests of authors and States parties' obligations in relation to the rights to food, health and education, as well as the rights to take part in cultural life and to enjoy the benefits of scientific progress and its applications, or any other right recognized in the Covenant.

These specific obligations may be more generally categorized into three "levels" or "types" of obligations by member states toward the rights of authors: to respect, to protect, and to fulfill. See id. 139 . 
In the end, the drafting processes of these documents are characterized more by the similarity among the participants than by their differences. Peter Yu notes that, notwithstanding their differences, the human rights instruments discussed above do not dictate a particular level of protection with respect to the right to the protection of intellectual creations. Thus, "the drafting history strongly suggests that the drafters were determined to create a universal document." ${ }^{36}$ Yet, there remain differing opinions concerning whether intellectual property rights such as copyright can properly be considered within the scope of human rights. It is fair to say that although some types of intellectual property rights legitimately can be seen as having a strong human rights basis, this is not necessarily the case with all intellectual property rights. ${ }^{37}$

Despite the conceptual and practical difficulties of viewing all intellectual property rights as human rights, moral rights present a special situation. Although moral rights may not rise to the level of other rights we think of as human rights, arguably they present a more compelling case for human rights based on their concern with the dignity of human beings. Laurence Helfer, pointing to the CESCR's 2005 General Comment, emphasizes a core moral type of right embracing a "zone of personal autonomy in which authors can achieve their creative potential, control their productive output, and lead independent, intellectual lives.” ${ }^{99}$ Paul Torremans suggests that " $[\mathrm{t}]$ he higher the level of creativity and the more important the input of the creator is, the stronger the Human Rights claim." "This observation would appear to underscore the human rights significance for works meeting the standard of heightened originality with substantial creativity. Peter Drahos also hesitatingly posits that a personalitybased theory might justify at least some intellectual property rights as human rights. ${ }^{41}$

${ }^{36} \mathrm{Yu}$, supra note 11 , at 1142.

${ }^{37} I d$. at 1077.

${ }^{38}$ See Torremans, supra note 9, at 16-17 ("From a Human Rights perspective the author or creator assumes also a lot of importance [that] manifests itself in the work produced ... being acknowledged as having an intrinsic value as an expression of human dignity and creativity."); cf. Rochelle Cooper Dreyfuss, Patents and Human Rights: Where Is the Paradox? in Intellectual Property and Human Rights: A Paradox 72 (Willem Groscheide, ed., 2010) (differentiating copyrights from patents on the ground that human dignity concerns may be implicated with respect to works of authorship but not inventions). ${ }^{39}$ See Helfer, supra note 30, at 996 (noting the existence of a core material right for authors and that any additional intellectual property protections beyond these core rights must balance public access considerations).

${ }^{40}$ Torremans, supra note 9 , at 19.

"WIPO, Peter Drahos, The Universality of Intellectual Property Rights: Origins and 
Still, the issue of moral rights being accepted as a human right is far from an easy call. In the first place, to the extent something is categorized as a human right, it is beyond the power of individual states to adjust for their convenience or preference. ${ }^{42}$ As the late Professor H. G. Schemers concluded, "human rights are of such importance that their international protection includes the right, perhaps even the obligation, of international enforcement." ${ }^{13}$ Moreover, even if one were to accept the premise that, notwithstanding the above concern, universal recognition equates to a universal, human rights norm as a general matter, ${ }^{4}$ with respect to moral rights there is the additional complication that they are not universally recognized, or at least not recognized in a universal manner. In discussing the historical compliance with Article 6bis of Berne, Justin Hughes has observed that "state practice has been so varied that heightened deference to national autonomy should pervade any analysis of the 6 bis provisions." ${ }^{\prime 5}$ Specifically, he demonstrates that in the period following 1928, several Berne members complied with their 6bis obligations in a weak manner that was very similar to current compliance by the United States. ${ }^{46}$ Presently, universal recognition presents an especially high hurdle in light of the United States' failure to embrace its moral rights obligation under Berne. The United States was particularly instrumental in the elimination of article Gbis from the TRIPS agreement, and thus successfully avoided being subjected to the mandatory dispute resolution process on moral rights despite our obligation to enforce moral rights pursuant to Berne. ${ }^{47}$

At best, then, we can say that moral rights enjoy widespread recognition. For example, the history of the drafting of the UDHR and ICESCR shows that although there may not have been a universal consensus as to whether moral rights are human rights, there was a significant recognition that these interests are deemed worthy of protection

https://www.wipo.int/edocs/mdocs/tk/en/wipo_unhchr_ip_pnl_98/wipo_unhchr_ip_pnl_98 1.pdf.

${ }^{12}$ Id. at 15 .

${ }^{43}$ H. G. Schemers, The International Protection of the Right of Property, in Protecting Human Rights: The European Dimension 579 (F. Matscher \& H. Petzold eds., 1988).

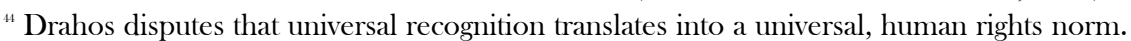
Instead, with respect to intellectual property rights as a general matter, he argues that such rights should be seen as instrumental rights through which other types of human rights can be fashioned. Drahos, supra note 41, at 22.

${ }^{45}$ Justin Hughes, American Moral Rights and Fixing the Dastar "Gap", 2007 UtaH L. Rev. 659,712 .

${ }^{46} \mathrm{Id}$. at 706 (noting that "most major common law countries-and several significant civil law countries-were members of the Berne Convention for decades before they passed moral rights statutes for the two Article 6bis rights").

${ }^{4}$ See KWALL, supra note 2, at 180 n.8-9 and accompanying text. 
in a human rights framework. I suggest that rather than asking whether moral rights are within the scope of human rights, it is more appropriate to focus on moral rights as "authorship norms," or common rules of engagement shared among the majority of interested citizens. Although traditionally norms are developed and enforced outside the legal system, ${ }^{48}$ they also can influence the development of the law by creating de facto standards that can either substitute for the law or encourage legal compliance. ${ }^{19}$ Thus, if attribution and integrity interests are understood as widespread authorship norms, the question is whether and how these norms ought to be translated into our legal system.

In bolstering the claim that attribution and integrity interests constitute authorship norms, it is instructive to consider legal traditions in addition to those of the common and civil law. Jewish law presents a distinct legal tradition that can be mined for its treatment of these interests.

Although most intellectual property laws are derived from the system of royal privilege-giving prevalent in medieval Europe, ${ }^{50}$ the origins of intellectual property law under the Jewish legal system are unique. Jewish copyright law originated with a dispute in the sixteenth century involving the unauthorized copying of a new edition of Moses Maimonides's code of Jewish law along with original commentaries. ${ }^{51}$

With respect to attribution and integrity interests, however, the origins of Jewish law are far more ancient. In fact, according to Jewish tradition, a lack of regard for these interests was the cause of the first sin and thus responsible for the downfall of humanity. In chapter 2, verse I7 of Genesis, God commanded Adam not to eat from the Tree of Knowledge. ${ }^{52}$ In chapter 3, verse 3 of Genesis, Eve tells the serpent that she may not eat the

\footnotetext{
${ }^{18}$ Jennifer E. Rothman, The Questionable Use of Custom in Intellectual Property, 93 VA. L. REV. 1899, 1900 n.1 (2007).

${ }^{4}$ See id. at 1902-06 (discussing the incorporation of customary law into IP decisions); see also Mark F. Schultz, Copynorms: Copyright Law and Social Norms, in 1 Intellectual Property and Information Wealth 201, 206-07 (Peter K. Yu ed., 2006) (focusing on the compliance aspects of file-sharing).

${ }^{50}$ Drahos, supra note 41 , at 2 . Roman law, which was heavily influenced by Greek thought, was the source for both the common and civil law European systems. See Mladen Vukmir, The Roots of Anglo-American Intellectual Property Law in Roman Law, 32 IDEA 123, 127, 151-52 (1991-92).

${ }^{51}$ See Neil Netanel, Maharam of Padua v. Giustiniani: The Sixteenth-Century Origins of the Jewish Law of Copyright, 44 Hous. L. REv. 821 (2007) for a detailed account of this case. One of the complicating features of this situation was that the defendant was not Jewish, which forced the judge to grapple with the thorny issue of the extent to which Jewish law could govern the conduct of a Gentile.

${ }^{52}$ Etz Hayim: Torah And Commentary 15 (David L. Lieber et al. eds., 2001).
} 
fruit or touch it, or she will die. ${ }^{53}$ The tradition of the Oral Law, used by Rabbinic authorities to understand Biblical passages, reveals that the serpent shoved Eve against the fruit and then said to her, "See, you did not die." As she saw that she did not die from touching the fruit, the serpent convinced her that there would be no negative consequences from eating the fruit. The tradition then explains how this happened. Adam wanted to add a safeguard on the commandment of not eating the fruit, so he said not to even touch it. Nonetheless, Adam did not tell Eve that the commandment not to touch the fruit was his own innovation. He let her think that is was God's commandment. Thus, according to Jewish tradition, by modifying God's original statement and by not correctly identifying what was God's command and what was his own addition, Adam triggered the expulsion from Eden. ${ }^{54}$ In this narrative, Adam's incorporation of the safeguard regarding not touching the fruit and his failure to properly attribute this safeguard violated the meaning and message of God's original words. The parallel between human and Divine creativity is emphasized in the Rabbinic tradition that understands human creativity as rooted in the inspirational element of mirroring God's creative capacities. ${ }^{5.5}$

Jewish law regarding attribution and integrity flows from the concept of duty as opposed to right. Although the moral lesson regarding the rights of attribution and integrity derives from this Creation narrative in Genesis, all relevant works of Jewish law on these points cite as the direct legal source a statement from the Ethics of the Fathers, a tractate embodying the accumulated ethical and moral wisdom of the Jewish Sages dating back to between 200 and $500 \mathrm{CE} \cdot{ }^{56}$ The importance of having one's words properly attributed to the original source is emphasized in the Ethics of the Fathers in the following verse: "Whoever repeats a thing in the name of the one who said it brings redemption to the world. ${ }^{, 57}$ The commentary emphasizes that "[o]ne must display indebtedness to a source and mention him by name," thus proscribing taking false credit for someone else's statement. ${ }^{58}$ This verse

\footnotetext{
${ }^{53} I d$. at 18.

${ }^{5 t}$ Moshe Weissman, The Midrash Says 45-46 (1980). According to this interpretation, Adam violated God's right of attribution by misattributing to God words that He did not speak (specifically, the injunction not to touch the fruit). He also violated God's right of integrity by modifying God's original commandments.

${ }^{35}$ See KWALL, supra note 2, at 13 n.16, 21, and accompanying text.

${ }^{56}$ Ethics of the Fathers: Pirkei Avos (Mesorah Publ'ns 1984); see also Berel Wein, Pirkei Avos, Teachings For Our Times (2003) (noting that chapter six is a later addition to the rest of the text dating back to around the fourth or fifth century rather than around $200 \mathrm{CE}$ ).

${ }^{57}$ Ethics of The Fathers: Pirkei Avos, supra note 56, at Ch. 6, § 6, 59.

${ }^{58}$ Id. at 59 n.6 (commentary by Rabbi Meir Zlotowitz).
} 
also implicitly embodies a responsibility to quote the source accurately. Based on the language of this tractate, the responsibility for accurate quotation and attribution is viewed as a duty of the second speaker rather than a right of the first speaker. A duty, indeed, is perpetual; a right lasts only so long as the first speaker or her representative has the ability to enforce it.

The Ethics of the Fathers is contained in the Talmud, the central book of Jewish law encompassing over forty tractates of materials with a multitude of commentary. ${ }^{59}$ Significantly, the Talmud as a whole underscores the importance of attribution by establishing attribution through several generations of students and teachers. ${ }^{60}$ For example, from an attribution standpoint, the phrase "Rabbi X said" as used in the Talmud does not necessarily mean "Rabbi X himself" but rather Rabbi X's later disciples. In the case of a disciple quoting his master, the omission of the true author or source was "probably a matter of convenience." ${ }^{62}$ Authorship of the material in the Talmud thus cannot be regarded the same as authorship in Western terms. ${ }^{63}$ In contrast, as Jewish Studies scholar Sacha Stern notes, "if the true author of a saying is not obvious or known to all, failure to attribute is considered plagiaristic and condemned." ${ }^{\prime \prime}$ Therefore, because the idea of misattribution in the Talmud must be accessed within its tradition of flexible, collection authorship, ${ }^{65}$ "only deceptive plagiarism would have constituted a breach of the practice of attribution." ${ }^{96}$

In contrast to Jewish law's morally based concern with attribution and integrity interests, the censorship and licensing regimes in seventeenthcentury England with respect to literary works represent some of the earliest de facto attribution and integrity protections. In order to earn the exclusive copyright protection of the Stationers' Company charter, a publisher needed to obtain the author's written permission. ${ }^{67}$ Specifically, once the censors operating in connection with the Stationers' Company in London

\footnotetext{
${ }^{59}$ Ethics of the Fathers, Babylonian Talmud, Nezikin.

${ }^{60}$ See generally Sacha Stern, Attribution and Authorship in the Babylonian Talmud, $45 \mathrm{~J}$. JEWISH STUD. 28 (1994).

${ }^{61} I d$. at $47-48$.

${ }^{62}$ Id. at 47 .

${ }^{63}$ Stern notes that since any "sayer" of a saying in the Talmud was always seen as "the bearer ... of his masters' teachings and of other earlier traditions," it is inappropriate to consider "any attributee . . . as an 'author' in the full, modern Western sense of the term." Id. at 51.

${ }^{61}$ Id. at 46 .

${ }^{65} \mathrm{Id}$. at $50-51$.

${ }^{66} \mathrm{Id}$. at 47.

${ }^{67}$ Siva Vaidhyanathan, Copyrights and Copywrongs: The Rise of Intellectual Property and How it Threatens Creativity 37-38 (2001).
} 
approved a particular version of a book, a bookseller had an exclusive license to print that would be jeopardized by making modifications. Moreover, licensing protected against an author being designated as the author of a work she did not create. In addition, as Susan Liemer has observed, "misattribution or modification of a work would thwart the registration system upon which the monopoly relied, because then something other than the registered work would be competing in the marketplace. ${ }^{{ }^{6} 8}$ Thus, this intricate dynamic protected aspects of authors' rights in a limited way, although the impetus was economic concern with works registered to guild members rather than a focus on authorship dignity. Still, there was general displeasure by authors with respect to their overall lack of control regarding their creations.

Moral rights developed in the civil law tradition in the nineteenth century, and it is in this milieu that we see most clearly the author's personal interest in her creations as a justification for embracing moral rights as authorship norms. ${ }^{69}$ The French choice of the term "moral" for the designation of this personality interest underscores the idea of moral rights encompassing authorship norms given that the French definition of "moral" has a broad meaning that pertains to principles or rules of appropriate conduct in a particular society. ${ }^{70}$ Moreover, the civil law tradition supports both attribution and integrity interests equally as authorship norms. In contrast, the United States copyright discourse has always been very rights centered. Utilitarianism is the predominant copyright justification in the United States, as evidenced by the Copyright Clause's affording protection for a limited time as an incentive to create. ${ }^{71}$ Although the history of the Copyright Clause specifically contains evidence of a focus on utilitarian

\footnotetext{
${ }^{68}$ Susan P. Liemer, How We Lost Our Moral Rights and the Door Closed on Non-Economic Values in Copyright, 5 J. Marshall Rev. Intell. Prop. L. 1, 11 (2005).

${ }^{69}$ See Kwall, supra note 2, at 39-40 n.22-34 and accompanying text (describing the "growing acceptance" of a writer's interests in her own work as similar to individual property rights in early nineteenth century France).

${ }^{70}$ Pluridictionnaire Larousse: Dictionnaire Encyclopedique De L'enseignement 911 (1st ed. 1975) (defining "moral" as (1) "qui concerne les regles de conduites en usage clans une societe determine" [pertaining to rules of behavior in a particular society], and (2) "se dit de ce qui est relatif a l'esprit, de ce qui est intellectuel (par opposition materiel, physique)" [pertaining to the spirit, concerned with the intellect (rather than material and physical)]). The English definition of "moral" encompasses this same idea. See Moral, MERriam Webster's Dictionary (defining “moral” as "of or relating to principles of right and wrong in behavior," or as "perceptual or psychological rather than tangible or practical in nature or effect”), www.merriam-webster.com/dictionary/moral (last visited Jan. 2, 2020). ${ }^{7}$ See KWALL, supra note 2, at 23 ("In reality, the United States had inherited from England a set of conflicting messages regarding authors' rights, in which economic protections were closely intertwined with personal rights.”).
} 
concerns, this perspective does not have to represent the entire story. Assuming the ongoing relevance of the utilitarian conception that has shaped our thinking about copyrights, the question is whether we are free at this point in time to incorporate additional narratives into the discourseshaping copyright law. I suggest that we are free to do so ${ }^{72}$ and that pursuant to this perspective, copyright law should be assessed in the context of a more fluid, multidimensional approach.

In recent years, scholars and even the judiciary are beginning to call for a more nuanced approach to intellectual property law generally. For example, both Madhavi Sunder and Peter Yu have argued that the utilitarian, economically oriented justifications for intellectual property are insufficient, and, therefore, a broader spectrum of justifications is needed. Specifically, Yu maintains that there is a need for the development of a holistic perspective on intellectual property so that the interface between intellectual property and human rights can be more fully mined. ${ }^{73}$ Sunder contends that "intellectual property is about social relations and should serve human values." ${ }^{\prime 7}$ Thus, whereas the traditional narrative of economic incentive is concerned with fostering creativity, a narrative steeped in social and cultural theory offers a "broader normative purpose for intellectual property." ${ }^{75}$ Peter Drahos posits an instrumentalist view of intellectual property that echoes similar themes. He believes that the rights created through intellectual property laws should serve fundamental human needs and values. ${ }^{76}$ In his view, therefore, "[v]iewing intellectual property through the prism of human rights discourse will encourage us to think about ways in which the property mechanism might be reshaped to include interests and needs that it currently does not."

This theoretical approach suggests that we should be considering copyright law's underlying theoretical framework as encompassing more than just the conventional utilitarian justification. In $M G M_{V} . G$ rokster ${ }^{78}$ the

\footnotetext{
${ }^{72}$ The novelty of the perspective developed in the text is reflected in the recent statement by a district court that "[c]opyight and trademark law are not matters of strong moral principle." Rather, "[i]ntellectual property regimes are economic legislation based on policy decisions that assign rights based on assessments of what legal rules will produce the greatest economic good for society as a whole.” Louis Feraud Int'l S.A.R.L. v. Viewfinder, Inc., 406 F. Supp. 2d 274, 281 (S.D.N.Y. 2005).

${ }^{73} \mathrm{Yu}$, supra note 11, at 1137.

${ }^{74}$ Madhavi Sunder, IP3, 59 STAN. L. REv. 257, 331 (2006).

${ }^{75} \mathrm{Id}$.

${ }^{76}$ Drahos, supra note 41 , at 24.

${ }^{77}$ Id. at 25; see also Torremans, supra note 9, at 9 (noting that copyright and intellectual property rights were included in the human rights instruments only because they were viewed "as tools to give effect to and to protect other stronger Human Rights").

${ }^{78}$ See MGM Studios, Inc. v. Grokster, Ltd., 545 U.S. 913 (2005).
} 
Supreme Court implicitly endorsed this very approach by holding that a defendant can be liable for inducing copyright infringement, even absent specific statutory authority in the copyright statute. ${ }^{79}$ In Grokster, the defendants distributed software that enabled users to exchange digital media through a peer-to-peer transfer network entirely outside of the defendants' control. ${ }^{80}$ The Court invoked the doctrine of inducement familiar under patent law as the basis for the defendants' liability. ${ }^{81}$ According to the majority opinion, "the record was replete with evidence that from the moment [the defendants] began to distribute their free software, each one clearly voiced the objective that recipients use it to download copyrighted works, and each took active steps to encourage infringement." ${ }^{{ }^{82}}$ This result has been applauded on moral and ethical grounds. ${ }^{83}$ In commenting on this decision, Madhavi Sunder notes that "the Supreme Court chose to impose liability for what it saw as moral wrongdoing" rather than sanctify the economic argument as "supreme over all other arguments."

\footnotetext{
${ }^{79}$ The Court observed "that one who distributes a device with the object of promoting its use to infringe copyright, as shown by clear expression or other affirmative steps taken to foster infringement, is liable for the resulting acts of infringement by third parties." Id. at 936-37. ${ }^{80}$ The lower courts also concluded that no vicarious liability resulted because, given the lack of a centralized mechanism, the defendants lacked the ability to supervise and control the infringing conduct, which occurred after the products had passed to the end-users. See MGM Studios, Inc. v. Grokster, Ltd., 259 F. Supp. 2d 1029, 1041, 1045 (D. Cal. 2003), aff'd, 380 F.3d 1154, 1165 (9th Cir. 2004), vacated, 545 U.S. 913 (2005). In light of the Supreme Court's holding regarding inducement, the lower court did not determine the appropriate prospective application of third-party liability principles. Grokster, 545 U.S. at 941.

${ }^{81}$ See Mark A. Lemley, Inducing Patent Infringement, 39 U.C. DAvis L. Rev. 225, 233 (2005). ("The Court's opinion can be read merely to adopt the common law patent principle that those who advertise or affirmatively encourage others to infringe are liable for inducement.”).

${ }^{82}$ Grokster, 545 U.S. at 924.

${ }^{83}$ Immediately after the opinion was issued, Asher Meir, the Research Director at the Business Ethics Center in Jerusalem (an independent institute located in the Jerusalem College of Technology) wrote the following in an editorial in the Jerusalem Post:

I can't comment on whether the court's ruling is good law, but I can say that it is good ethics. A firm can't take a 'see no evil, hear no evil, speak no evil' approach to the use of its product if there is a significant chance it is being improperly used, or if there is any active connivance in such improper use I believe that the clear ethical message of this ruling will be helpful in clarifying the importance of intellectual property rights.

Asher Meir, Grokster File-Sharing and Glue-Sniffing, Jerusalem Post, July 3, 2005, at 17. According to Julie Sigall, the Associate Registrar for Policy and International Affairs at the Copyright Office, most participants in the Grokster decision are "reasonably satisfied" with the ruling and Congress has not been besieged with requests to modify the ruling. 71 PAT. TRADEMARK \& COPYRIGHTJ. (BNA) 667 (2006).

${ }^{84}$ See Sunder, supra note 74, at 286-88.
} 
A more fluid view of copyright generally would allow us to make room for the inclusion of the right of attribution and even a cabined right of integrity in our legal system. These rights are not concerned with economic reward but instead support a different agenda. A broader view of copyright would allow the United States to recognize explicitly the existence of authorship norms that support moral rights protection. John Merryman perceived these shared authorship norms years ago when he wrote that "the moral right is the product of legal development in western, bourgeois, capitalist nations with whom we have deep cultural affinity." ${ }^{85}$ He further remarked that "even though our legal traditions often seem quite different from theirs, the differences are superimposed on a common, shared cultural base. ${ }^{\text {"6 }}$ Indeed, the Final Report of the Ad Hoc Working Group on the United States' Adherence to the Berne Convention similarly recognizes attribution and integrity as part of the authorship norms of "fair dealing." The Report states that "[f]ailure to identify the author on the work defeats the statutory purpose; and is 'unfair dealing' with respect to the author and public." ${ }^{87}$ It also recognized the norms of integrity protections by noting that courts could protect against integrity violations by invoking implied covenants of fair dealing and good faith, as well as resorting to industry practice to close contractual loopholes. ${ }^{88}$

Moreover, even within our current framework, attribution in particular exists as an authorship norm even if it is not explicitly codified in the copyright statute. Attribution violations in general and plagiarism in particular are viewed as moral wrongs in our society among both authors and audiences. ${ }^{89}$ Writing from a criminal law perspective with respect to

${ }^{85}$ John Henry Merryman, The Refrigerator of Bernard Buffet, 27 Hastings L.J. 1023, 1043 (1976).

${ }^{86}$ Id.

${ }^{87}$ Final Report of the Ad Hoc Working Group on U.S. Adherence to the Berne Convention, 10 COLUM.-VLAJ.L. \& ARTS 513, 552 n.19 (1985-86) (suggesting that an express contractual provision allowing omission of the author's name would be unenforceable as against copyright policy).

${ }^{88} I d$. at 555 .

${ }^{89}$ Rebecca Tushnet, Naming Rights: Attribution and Law, 2007 UTAH L. REV. 781, 783 n.11 (2007); Greg Lastowka, The Trademark Function of Authorship, 85 B.U. L. REv. 1171, 1184-85 (2005) (stating that "even in this postmodern era, anti-plagiarism norms remain quite strong”); Stuart P. Green, Plagiarism, Norms, and the Limits of Theft Law: Some Observations on the Use of Criminal Sanctions in Enforcing Intellectual Property Rights, 54 HASTINGS L.J. 167, 175 (2002) (noting that people view attribution as similar to a "moral obligation"); see also Henry Hansmann \& Marina Santilli, Authors'and Artists' Moral Rights: A Comparative Legal and Economic Analysis, 26 J. Legal STud. 95, 130-31 (1997) (noting that the negative right of attribution is "relatively unproblematic" and "has obvious utility in protecting artists from theft of the reputation they have cultivated and in protecting the public 
plagiarism, Stuart Green calls the "norm of attribution" as one grounded in the desire for esteem. ${ }^{90}$ He sees plagiarism as a corollary to the rule of attribution and argues that they constitute a "powerful pair of social norms." ${ }^{.1}$ Although attribution and plagiarism share a somewhat similar theoretical basis, they do differ in important respects insofar as a moral rights framework is concerned. First, whereas someone commits plagiarism by copying from deceased authors, the theory underlying the moral right of attribution really applies with the most force during the author's lifetime. ${ }^{92}$ Also, the norms of plagiarism are such that the conduct is adjudicated and punished largely within the confines of academic or other such particularized professional spheres. ${ }^{93}$ Lastly, plagiarism can occur even if the offender takes a relatively small amount of material or work that is otherwise unprotected by copyright law. ${ }^{94}$ In contrast, an attribution violation should only be triggered when the offender takes something from a work protected by copyright law (indeed the argument was made that moral rights should apply only to a subset of copyrightable works). ${ }^{95}$

Notwithstanding these distinctions, however, both attribution and plagiarism share a concern for giving credit where credit is due. With respect to both attribution and plagiarism violations, the offender "steals" the credit

at large from being misled"). But see Michael Landau, Dastar v. Twentieth Century Fox: The Need for Stronger Protection of Attribution Rights in the United States, 61 N.Y.U. ANN. SurV. AM. L. 273, 298 (2005) (stating that "copying a work without giving attribution is plagiarism, and the Court ... is giving its blessing to the practice").

${ }^{90}$ Green, supra note 89, at 174 . He traces the concept of plagiarism back to both Jewish and Roman law. Id. at 177; see also Harold C. Streibich, The Moral Right of Ownership to Intellectual Property: Part I-From the Beginning to the Age of Printing, 6 MEM. ST. U. L. REv. 1, 5-6 (1975) (noting that both Greek and Roman culture "'stigmatized' plagiarism as a crime," despite little enforcement "of the 'moral right' of a creator to his work" (citing G.H. Putnam, Authors And Their Public in Ancient Times 68 (3d ed. rev. 1896))). Note also that the term plagiarism is derived from the Latin term for kidnapping. KWALL, supra note 2 , at $14 \mathrm{n} .26$ and accompanying text.

${ }^{91}$ Green, supra note 89, at 195.

${ }^{92}$ But see KWALL, supra note 2, at 46 n.88-89 and accompanying text.

${ }_{93}^{93}$ Green, supra note 89, at 199; David Nimmer, The Moral Imperative Against Academic Plagiarism (Without a Moral Right Against Reverse Passing Off), 54 DePaul L. Rev. 1 (2004) (endorsing the result in Dastar with respect to reverse passing off as a general matter but approving the norms of plagiarism in specialized settings such as the academy); Rebecca Tushnet, Payment in Credit: Copyright Law and Subcultural Creativity, 70 LAw \& CONTEMP. Probs., Spring 2007, at 135, 155 (noting that among the community of fan creators, plagiarism is "one of the most serious offenses" and that when such conduct surfaces, "fans are likely to publicly excoriate the plagiarist").

${ }^{94}$ Green, supra note 89, at 201; see also Landau, supra note 89, at 307-10.

${ }^{95}$ See discussion in KWALl, supra note 2, ch. 6 at 69-85. 
to which the true author is entitled..$^{96}$ The notion that such "theft" is simply wrong represents a powerful authorship norm. Attribution is garnering increased attention by scholars working in law, the sciences, and the humanities. ${ }^{97}$ Interestingly, in the intellectual property academy, both low protectionists as well as high protectionists have proposed enhanced protections for attribution. Although it is not surprising that the high protectionists who otherwise favor increased moral rights protections would urge stronger attribution interests, ${ }^{98}$ Rebecca Tushnet notes that even low protectionists who place the public interest over that of authors are advancing attribution concerns as "a matter of fairness to authors." Jennifer Rothman argues that attribution customs deserve more consideration because they are motivated by aspirational objectives rather than goals such as avoiding litigation. ${ }^{100}$ Greg Lastowka notes that providing attribution protection "would acknowledge the fundamentally different dynamics of open copyright practices and promote the smooth functioning of reputation economies." ${ }^{101}$ Scholars also have demonstrated that attribution is important in a wide variety of creative enterprises including cuisine and even scholarship by law professors. ${ }^{102}$

In the United States, the right of integrity is viewed with far more suspicion and resistance than the right of attribution, largely as a result of a

${ }^{96}$ Green, supra note 89, at 219.

${ }^{97}$ Catherine L. Fisk, Credit Where It's Due: The Laws and Norms of Attribution, 95 Geo. L.J. 49, 52 (2006).

${ }^{9}$ See, e.g., Jane C. Ginsburg, The Right to Claim Authorship in U.S. Copyright and Trademark Law, 41 Hous. L. Rev. 263, 304 (2004).

${ }^{99}$ Tushnet, supra note 89 , at 785.

${ }^{100}$ Rothman, supra note 48, at 1947-48.

${ }^{101}$ Greg Lastowka, Digital.Attribution: Copyright and the Right to Credit, 87 B.U. L. REv. 41, 78 (2007).

${ }^{102}$ See id. at 60-61 (noting that according to a survey of French chefs, the most important norm governing recipe sharing was the expectation of proper attribution, and positing that law professors also are motivated by reputational profits); see also Emmanuelle Fauchart \& Eric von Hippel, Norms-Based Intellectual Property Systems: The Case of French Chefs, 19 ORG. SCI. 187, 193 (2008); KWALL, supra note 2, ch. 7 at 87 (discussing the development of prevalent attribution norms by various communities).

The momentum for attribution rights was reflected in a previously proposed attribution rule by the Copyright Office that would allow people to copy "orphan works" whose copyright owners are known but not capable of being located, as long as attribution to both the author and the copyright owner is provided. See Register of Copyrights, U.S. Copyright OFFICE, REPORT ON ORPHAN WORKS 110-11 (2006), www.copyright.gov/orphan/orphanreport-full.pdf. As of this writing, the 2006 bill has been withdrawn, but an amended Orphan Works Reform Bill is working its way through Congress. The current version specifies attribution only "to the legal owner of the infringed copyright." S. 2913, 110th Cong. (as passed by Senate, Sept. 26, 2008). 
culture emphasizing strong First Amendment and public access values. As a result of these concerns, theorists question why the voice of the author of the original text should be privileged above subsequent creators. ${ }^{103}$ Charles Beitz indicates that, with respect to the issue of privileging, moral rights laws should somehow take into account the degree to which a work is well known and widely recognized. ${ }^{104}$ Although Beitz does not specifically say why this should be the case, I suggest that the reason has to do with the underlying theory of moral rights as a legal measure designed to safeguard the dignity interests of authors. Dignity interests of the author are realized in the external embodiments of the author's inner creative process. ${ }^{105}$ Underlying the importance of the external is, I believe, the idea of the author's esteem that derives from a public acknowledgment of her creative efforts. Authorship dignity is facilitated by an appropriate regard for a work's meaning and for the external embodiment of an author's work as the means through which her message is communicated to the public. As seen through this lens, the damage resulting from a right of integrity violation is particularly problematic when the modified work is linked to the author through specific attribution or widespread public recognition.

Thus, although attribution may present a more clear-cut, and easierto-administer area than the right of integrity, both are deeply concerned with the author's dignity and esteem. In order for a right of integrity to be viable in the United States, it will need to balance carefully competing interests and incorporate a large degree of cabining measures. Interestingly, such balancing is characteristic of the human rights instruments discussed at the beginning of this article. Both the UDHR and ICESCR contain, in addition to the provisions calling for the author's right to be protected with respect to her moral and material interests, ${ }^{106}$ separate provisions emphasizing the public's right to enjoy and benefit from works. ${ }^{107}$ In light of the challenge ahead for the right of integrity specifically, and moral rights as a whole, a new paradigm beyond VARA is needed for these interests.

\footnotetext{
${ }^{103}$ See Charles Beitz, The Moral Rights of Creators of Artistic and Literary Works, 13 J. PoL. PHIL. 330, 349 (2005).

${ }^{101} I d$.

${ }^{105}$ See KWALL, supra note 2, at 4-5 n.13-17 and accompanying text.

${ }^{106}$ See supra notes $11 \& 20$ and accompanying text.

${ }^{107}$ See supra notes $11 \& 27$ and accompanying text. Helfer notes that balancing the public's interests with those of creators and inventors represents "one of the most challenging tasks" for the CESCR. Helfer, An Uneasy Alliance, supra note 21, at 88. To date, the CESCR has not drafted general comments interpreting the other subsections of Article 15 that protect the public's rights. $I d$. at 112 .
} 


\section{Mitchell Hamline Law Review}

The Mitchell Hamline Law Review is a student-edited journal. Founded in 1974, the Law Review publishes timely articles of regional, national and international interest for legal practitioners, scholars, and lawmakers. Judges throughout the United States regularly cite the Law Review in their opinions. Academic journals, textbooks, and treatises frequently cite the Law Review as well. It can be found in nearly all U.S. law school libraries and online. mitchellhamline.edu/lawreview

\section{$\mathrm{MH}$}

MITCHELL | HAMLINE

School of Law

(c) Mitchell Hamline School of Law 875 Summit Avenue, Saint Paul, MN 55105

mitchellhamline.edu 